\title{
Revelation on Space Organization and Management Model of Development Zone in China Based on Edge City Theory
}

\author{
Chen Chen, Lei Niu \& Yuhua Wang \\ College of Water Resources \& Civil Engineering, China Agricultural University, Beijing
}

\begin{abstract}
Some problems emerges with the rapid growing of development zone in China. Edge city in America is the consequence of spread development with the similar features of development zone in China which is worth learning. By sorting out related theory of edge city and comparing it with development zone on space organization and management model based on China's conditions, we suggest that government should construct public transport, link development zone and center zone, reduce government involvement properly, give full play to the role of the market in resource configuration, clearly position the main functions of employment, construct the infrastructure, develop the tertiary industry and reduce the environmental pollution, making development zone more suitable.
\end{abstract}

KEYWORD: edge city; development zone; space organization; management model

\section{INTRODUCTION}

There are 210 national economic development zone in China till 2013 with 103 in the east, 47 in the central and 47 in the west. It is shows that the GDP of all the 171 national economic development zone in 2012 is 5.3916 trillion yuan with $10.4 \%$ of the country which was increased by $30.4 \%$ in 2011(Investment Promotion Agency of the Ministry of Commerce \& Commerce Department Academy of International Trade and Economic Cooperation.2013). However, due to some shortage on management model and space organization, some problems emerge with the rapid development of development zone, such as the lack of motivation, weak roots, less innovation, foreign dependence excessive, inadequate facilities and so on(Zhifang Tian.2008, Xingping Wang \& Xinguo Yuan.2009). All the problems above constrained the development of development zones.

Edge city in America is the consequence of spread development with the similar features of development zone in China which is worth learning. The theory of edge city was put forward by Garrau(1991) with five defining standards, including affordable office, ratail commercial area, the number of jobs should exceed the number of bedrooms and so on(Garrau J ,1991). Stanback thought edge city is the product suburbanization and counterurbanization made a supplement to the standard that the define of edge city should take the location factors into account and edge city should be built at the intersection of the edge of the main road or highway intersection suburbs(Stanback T M. 1991).

Edge city theory was introduced into China by Sun Yifei in 1997 and some domestic scholars integrate China's national conditions and made some practice research. Some scholars contrast Yizhuang of Beijing and Kunshan of Shanghai and conclude that edge city is a product of the new economic growth phase and is similar with some space model in after west suburbanization which is emerging in the edge of some big cities(Meikie $\mathrm{J}$ and Atkinson D. 1997,Yue Deng et al.2001). By researching development zone of Ningbo and Fengtai, some scholars thing that the increasing union which is made of local government and real state developers is the major force that promotes the formation of edge city in Fengtai. We must put forward some distinctive redevelopment modes by considering the diverse and pluralistic features of development zone(Wei Li et al.2008, Xiao Juan.2003). Meanwhile, there are some representative features of space organization model in Songjiang (Xinguo Yuan \& Xingguo Yuan.2010). By combing some development zones of big city, some scholars extract main elements of China's edge city and further explore the main feature and defining standards of China's edge city (Zheng Guo \& Jing Meng.2012).

Overall, there are few research focusing on how to effectively make use of edge city theory to promote the development of development zone in 
China and lack of deep-seated study on space organization and management model. This article put forward some advice on space organization and management model of development zone by comparing, referring and analyzing edge city theory, in order to optimize and promote the space organization and management model of development zone.

\section{COMPARISON AND ANALYSIS ON SPACE ORGANIZATION}

\subsection{Space development location}

Some scholars think that we should build a Europe edge city network composed by many edge cities which should be located in the outskirts of the central city and reply on the traffic network of central city (Hui Cheng, et al.2012). China's development zones were located near to the central city at the beginning. With the bi-spread type development of both central city and development zone, the location of development zone has changed from suburbs far away to suburbs near by (Table 1). By rational planning and organizing public traffic network, we can promote the construction grade of road between development zone and central city, and development zone and main transport hub, so as to strengthen transport links, shorten travel time, contact development zone and central city closely, promote development zone with the core role of central city and achieve rapid development of the entire region.

Table 1. The distance between national level development zone and central urban area

\begin{tabular}{|c|c|c|c|}
\hline Region & Development zone of Tianjin & Development zone of Qingdao & Development zone of Guangzhou \\
\hline $\begin{array}{c}\text { Distance from central city } \\
(\mathrm{km})\end{array}$ & 50 & 3.7 & 22 \\
\hline
\end{tabular}

\subsection{Accessibility of the central area}

The development of edge city abroad is always along with the decline of central city. As high-income group transfer from central city to the edge, the tax revenue of the city reduced. As a result, the edge of the city and the center of town did not form a good relationship mutually reinforcing. The industry structure of mature edge city is more diverse and replace some function of the central city(Richard D Bingham \& Deborah Kimble.1995). Deborah found that 26 edge cities of Ohio are more special-purpose (Deborah.2001). Richard D. Bingham and Deborah Kimble recognized that most edge cities of Ohio are provide with one or more special function with obvious feature of specialization, and are with different functions with the central city (Arthur C Nelson.1993). Ryrum E thought the function of edge city is contributed by information technology, flexible and diffusion of the industry (Langqun Sun. 2005).
China is on the process of rapid urbanization with fast development of both central city and development zone, which means the relationship of central city and development zone are benign cooperation rather than competition. Take the development zone of Qingdao for instance (Table 2), the GDP of both central city and development zone are increased from 2009 to 2011 with the benign trend of mutural promotion. The space environment of development zone should transfer from expanding outside to improving the content, make use of favorable environment and broad space in order to undertaking the redundant industry of the central city and develop specialized industry, then it will become a complementary are of the central city. While the central city should take advantage of its leading role with the function of new area and old area distinguished. This is the effective way to achieve a win-win.

Table 2. The production value of each districts of Qingdao (2009-2011)

\begin{tabular}{|c|c|c|c|c|c|c|}
\hline \multirow{2}{*}{ Zoning } & \multicolumn{2}{|c|}{$\begin{array}{c}\text { Industrial output of } 2009 \\
(100 \text { million yuan })\end{array}$} & \multicolumn{2}{c|}{$\begin{array}{c}\text { Industrial output of } 2010 \\
(100 \text { million yuan })\end{array}$} & \multicolumn{2}{|c|}{$\begin{array}{c}\text { Industrial output of 2011 } \\
(100 \text { million yuan })\end{array}$} \\
\cline { 2 - 7 } & $\begin{array}{c}\text { secondary } \\
\text { industry }\end{array}$ & $\begin{array}{c}\text { tertiary } \\
\text { industry }\end{array}$ & $\begin{array}{c}\text { secondary } \\
\text { industry }\end{array}$ & $\begin{array}{c}\text { tertiary } \\
\text { industry }\end{array}$ & $\begin{array}{c}\text { secondary } \\
\text { industry }\end{array}$ & $\begin{array}{c}\text { tertiary } \\
\text { industry }\end{array}$ \\
\hline Development Zone & 549.33 & 277.43 & 654.25 & 345.15 & 750.12 & 420.28 \\
\hline Shinan district & 56.91 & 421.16 & 59.50 & 484.20 & 63.05 & 571.16 \\
\hline Shibei district & 51.00 & 196.21 & 54.17 & 225.95 & 54.99 & 262.71 \\
\hline Licang district & 105.37 & 81.78 & 117.93 & 95.31 & 128.53 & 118.83 \\
\hline
\end{tabular}




\subsection{Space traffic organization}

In the term of space traffic organization, Sun Langqun found that the widely use of private car is one of the most important reason of rapid suburbanization in America by investigation and the suburbanization of population is the direct impetus of the emerging of edge city(Michael A Stern \&William M Marsh.1997). Michael A Stern and William M Marsh also considered the edge city of America is based on private car instead of public traffic network and this is one of the conditions of rapid emerging of edge city (Marco Bontje \& Joachim Burdack. 2005). Few of the workers in development zone of China has private car at present and most of them reply on public traffic network. The design route of public traffic bus, such as light rail, ferry and so on is very important to them (Jonas A E G. 1999).The phenomenon is consistent with the level of economic development of China and is hard to change in a short term. The development zone of China should either be consistent with this condition, vigorously develop public traffic and shorten the passage of time, in order to implement the shortcut and diverse arrival between central city and development zone.

\section{COMPARISON AND ANALYSIS ON MANAGEMENT MODEL}

\subsection{Main body of formation and control}

It is generally believed that the main force of the emerging of edge city is market instead of government. Real estate developer plays an important role in it by the attraction of interest $(\mathrm{R}$ Harris \& P Larkham. 1999). There is a private or half-public organization in charge of the government and incomplete exercise political funtion in the initial stage of edge city(Robert Holden \&Tom Turner. 1997). Robert Holden and Tom Turner studied some edge cities of Europe by GIS and found that there's no obvious administrative boundaries between edge cities with the feature of inter-regional cooperation (Renqiao Zhang.2003).

Nonetheless, scholars also point out that edge city is not a product that unplanned. The further development of edge city rely on the guide of government. Government regulate the edge city macroscopically in terms of market development and urban designing (Patrick S. McGovern. 1998). This contributes to the transformation from un-mature to mature and the safety and comfort of edge city (David L McKee \& Yosra A McKee. 2001).

The forging of edge city is promoted mainly by market with the phenomenon of suburbanization of population and business relocation. Meanwhile, the function of government has been greatly reduced and the invisible government emerged. In the contrast, the development zone in China is contributed mainly by government with clear position of space structure and development direction, such as the "one city, two cores, three bays" model of Tianjin(Table 3). Furthermore, the development zone is always in charge by CMC or development company with seriously staggered of powers of executive, un-clear administrative body and un-obvious guide of market factors. All the factors above result in a management confusion.

Table 3. The functional orientation of national level development zone

\begin{tabular}{|l|l|l|}
\hline Area & Position of city development & Position of space structure \\
\hline Tianjin & Bohai economic center, northern economic center and eco-city & One axis, two areas, three districts \\
\hline Qingdao & $\begin{array}{l}\text { International port city in eastern coast, coastal tourist resort } \\
\text { city }\end{array}$ & $\begin{array}{l}\text { Rely on central city, develop on bay, Group } \\
\text { layout, Axial radiation }\end{array}$ \\
\hline Shenyang & $\begin{array}{l}\text { Sheyang economic capital of Liaoning Province and the core } \\
\text { city area, the state of advanced equipment manufacturing base, } \\
\text { a national historical and cultural city, National Center City }\end{array}$ & $\begin{array}{l}\text { transfer from single-center cluster growth to } \\
\text { sustainable growth in multi-center of space } \\
\text { development model }\end{array}$ \\
\hline Guangzhou & $\begin{array}{l}\text { National Center City, comprehensive gateway cities of the } \\
\text { world cultural city }\end{array}$ & $\begin{array}{l}\text { One master, six association, many groups, two } \\
\text { centers, four nuclear, many multi-center }\end{array}$ \\
\hline
\end{tabular}

\subsection{Functional positioning and supporting facilities}

Because of short-sighted design and chaotic management, some development zones of China become "Sleeping City" with the main function of inhabitant. The proportion of industrial land in most development zones is higher than $50 \%$ with the main function of employment (Table 4). The facilities in development zone of China is imperfect with single function and necessary municipal facilities, making it hard to everyday life and transformation of industry structure (Richard D Bingham \& Deborah Kimble.1995).

Unlike development zone, edge city possesses improved facilities of transportation, medical, municipal and others, which can satisfy inhabitants with all welfare that of city. Many big companies in America relocated branches or headquarters to the outskirts since 1970, which greatly increased the employment outskirts. Marco Bontje and Joachim Burdack thought employment is the main function of edge city and supplement the five standard granted 
by Garrau, including highly concentrated employment is also the standard of edge ciy (Haixiao Pan \& Ying Zhang. 2002). DavidL. McKee and Yosra A. McKee classified as entrepreneurial type and corporate type, both with many kinds of infrastructure of High-end retail, entertainment and consumer services and possess the functions of inhabitant, employment and recreation $(\mathrm{Ge}$ Chen.2009).

Table 4. The land usage of national level development zone

\begin{tabular}{|l|c|c|c|}
\hline & $\begin{array}{c}\text { Built } \\
\text { industrial } \\
\text { area }\left(\mathrm{km}^{2}\right)\end{array}$ & $\begin{array}{c}\text { Industrial } \\
\text { area ratio } \\
(\%)\end{array}$ & $\begin{array}{c}\text { Other } \\
\text { area ratio } \\
(\%)\end{array}$ \\
\hline $\begin{array}{l}\text { Development zone } \\
\text { of Tianjin }\end{array}$ & 34 & 75.56 & 24.44 \\
\hline $\begin{array}{l}\text { Development zone } \\
\text { of Qingdao }\end{array}$ & 19 & 59.38 & 40.62 \\
\hline $\begin{array}{l}\text { Development zone } \\
\text { of Shenyang }\end{array}$ & 22 & 64.71 & 35.29 \\
\hline $\begin{array}{l}\text { Development zone } \\
\text { of Guangzhou }\end{array}$ & 25 & 63.29 & 36.71 \\
\hline
\end{tabular}

\subsection{Industrial structure and Environment}

Tertiary industry is the main body of edge city, including Retail trade, wholesale trade, production and services, social services, personal services and so on and different edge city has its special function. Richard D. Bingham classified edge cities to types of retail, manufacturing, healthcare, government and trade and tourism, with the overall leading role of tertiary industry (Marco Bontje \& Joachim Burdack. 2005). Marco Bontje thought the function of edge city of Europe is not merely industrial production, it is also high technical center (Michael A Stern \&William M Marsh.1997).

Most of development zones of China mainly reply on secondary industry, including manufacturing, heavy industry, construction and so on. As is shown in Table 5, the top 10 businesses of 210 national development zones in first half of 2012 are concentrated in manufacturing with $70.8 \%$ of all the GDP. The increase of tertiary industry output in recent years is about $20 \%-45 \%$, with large gap to the secondary industry yet. Edge city replaced traditional plant by industrial park. Unlike many industrial parks in China, that abroad is the real factory in garden with high greening rate and beautiful environment and attract many people in central city coming and working here. In the contrast, the industry park of development zone in China is mostly in chaotic, unsustainable development model, with high ratio of secondary industry and severe environment pollution (Wenhe Chen.2012).

Table5. The major economic indicator of national development zone in the first half of 2012

\begin{tabular}{|l|l|l|l|}
\hline Economic Indicators & 131 development zones \\
\hline & January-June, 2012 & January-June, 2011 & $\begin{array}{l}\text { compared with the same } \\
\text { period of last year }\end{array}$ \\
\hline GDP (100 million yuan) & 21860.5 & 19131.86 & $14.26 \%$ \\
\hline Secondary industry Incremental (100 million yuan) & 16450.73 & 12850.99 & $28.01 \%$ \\
\hline Industry Incremental (100 million yuan) & 15410.53 & 13652.65 & $12.88 \%$ \\
\hline Tertiary industry Incremental (100 million yuan) & 5135.12 & 4356.21 & $17.88 \%$ \\
\hline
\end{tabular}

\section{COMPREHENSIVE COMPARATIVE ANALYSIS}

By comparing and analyzing edge city and development zone, we can see that they are very similar with the same location of located in the outskirts of the central city and reply on the traffic network of central city. The development of edge city abroad is always along with the decline of central city, while the relationship of central city and development zone in China are benign cooperation rather than competition. The central city takes advantage of its leading role with the function of new area and old area distinguished. This is the effective way to achieve a win-win. Few of the workers in development zone of China has private car at present and most of them reply on public traffic network. The design route of public traffic bus, such as light rail, ferry and so on is very important to them, which is different from edge city (Table 6).

In terms of management model, the main force of the emerging of edge city is market instead of government. The function of government has been greatly reduced and the invisible government emerged. In the contrast, the development zone in China is contributed mainly by government with clear position of space structure and development direction. In development zone of China, the proportion of industrial land in most development zones is higher than $50 \%$ with the main function of employment. Edge city possesses improved facilities of transportation, medical, municipal and others, which can satisfy inhabitants with all welfare that of city. Tertiary industry is the main body of edge city, including Retail trade, wholesale trade, production 
and services, social services, personal services and so on and different edge city has its special function. Most of development zones of China mainly reply on secondary industry, including manufacturing, heavy industry, construction and so on. The industry park of development zone in China is mostly in chaotic, unsustainable development model, with high ratio of secondary industry and severe environment pollution (Table.6).

Tab.6 The compare between edge city and development zone

\begin{tabular}{|l|l|l|l|}
\hline \multicolumn{2}{|c|}{} & Edge city & Development Zone \\
\hline \multirow{3}{*}{$\begin{array}{l}\text { Space } \\
\text { organization }\end{array}$} & Space development location & \multicolumn{2}{|l|}{ Located in the outskirts of the main road interchanges } \\
\cline { 2 - 4 } & Accessibility of the central area & With the decline of central city & Collaborative development \\
\cline { 2 - 4 } & Space traffic organization & Mainly by private car & Mainly by public traffic \\
\hline \multirow{4}{*}{$\begin{array}{l}\text { Management } \\
\text { model }\end{array}$} & Main body of formation and control & Market, "invisible government" & Government, chaotic management \\
\cline { 2 - 4 } & $\begin{array}{l}\text { Functional positioning and } \\
\text { supporting facilities }\end{array}$ & Employment, perfect facilities & Employment, scarcity facilities \\
\cline { 2 - 5 } & Industrial structure and Environment & tertiary industry, good environment & Secondary industry, great pollution \\
\hline
\end{tabular}

\section{CONCLUSION AND SUGGESTION}

Edge city in America is the consequence of spread development with the similar features of development zone in China which is worth learning. By sorting out related theory of edge city and comparing it with development zone on space organization and management model based on China's conditions, we suggest that government should construct public transport, link development zone and center zone, reduce government involvement properly, give full play to the role of the market in resource configuration, clearly position the main functions of employment, construct the infrastructure, develop the tertiary industry and reduce the environmental pollution, making development zone more suitable.

The emerging of edge city is mainly promoted by market, yet further development relies on guide of government. Development zone is on the opposite with enough government design and lack of market guide. We should reduce government intervention, promote market development independently, make full use of the function of market in allocating resources and formatting more reasonable location combinations. In terms of administrative divisions, we should blur the administrative boundaries, reduce government management and make the market guide the growth of development zone. Meanwhile, it is also important to define the function of development zone, make employment the leading function, transfer industrial area properly and increase infrastructure construction, provide medical care, recreation, leisure and education area. In this way we can gradual improve urban functions and meet the daily needs of residents.

China is on the process of rapid urbanization with booming secondary industry, which meanwhile generate a lot of waste gas, waste water and solid waste. The positioning of cheap industrial park made development zone unreasonable developed, with loose supervision system making it worse. The government should adjust the structure of industry and transform development zone from cheap industrial park to high-tech innovation park, in order to improving the environment, attracting more inhabitants and making development zone more suitable.

\section{ACKNOWLEDGEMENTS}

The corresponding author of this paper is Yuhua Wang. This paper is supported by Study on the effect of the evolution mechanism of spatial organization of China's rural industry and regional resource environment in property right reform era, National Natural Science Foundation (41101122).

\section{REFERENCES}

[1] Arthur C Nelson.1993. Disamenity Influences of Edge Cities on Exurban Land Values: a Theory With Empirical Evidence and Policy Implications. Urban Studies.30(10): 1683-1690

[2] David L McKee \& Yosra A McKee. 2001. Edge Cities and the Viability of Metropolitan Economies: Contributions to Flexibility and External Linkages by New Urban Service Environments. American Journal of Economics and Sociology. 60(1): 171-184

[3] Deborah.2001.Edge Cities: Magnets for Development. Building Design \& Construction

[4] Garrau J, 1991. Edge City: life on the frontier. 1-10.

[5] Ge Chen.2009. Public Service Facilities System Development. Zhejiang University

[6] Haixiao Pan \& Ying Zhang.2002. Shanghai Rail Transitoriented development and public transportation Zone Introduction. Urban Planning Forum. 4:69-73,80

[7] Hui Cheng \& Yuting Liu \& Shenjing He.2012. Development-oriented Chinese characteristics "edge city" development. Urban Planning Forum.6:50-57 
[8] Investment Promotion Agency of the Ministry of Commerce \& Commerce Department Academy of International Trade and Economic Cooperation. 2013. National Economic and Technological Development Zone Industry Development Report.

[9] Jonas A E G. 1999.Making Edge City: Post-suburban Development and Life on the Frontier in Southern California

[10] Langqun Sun. 2005. American suburbanization of urban. Beijing: The Commercial Press

[11] Marco Bontje \& Joachim Burdack. 2005. Edge Cities, European-style: Examples from Paris and the Randstad. 22(4): 317-330

[12] Marco Bontje \& Joachim Burdack. 2005.Edge Cities, European-style: Examples from Paris and the Randstad.22(4): 317-330

[13] Meikie J and Atkinson D. 1997.Self-made Croydon Revamps Its Image as Glittering City of Europe. Guardian, 06-25(9)

[14] Michael A Stern \&William M Marsh.1997. The Decentered City: Edge Cities and the Expanding Metropolis. Landscape and Urban Planning.36(4):243-246

[15] Patrick S. McGovern. 1998. San Francisco Bay Area Edge Cities: New Roles for Planners and the General Plan. Journal of Planning Education and Research.17: 246-258

[16] R Harris \& P Larkham. 1999. Changing Suburbs: Foundation, form and Function. London: FN Spon. 202221

[17] Renqiao Zhang.2003. Metropolitan periphery of urban development - in Zhenjiang City as an example. Nanjing: Nanjing Normal University

[18] Richard D Bingham \& Deborah Kimble.1995. The Industrial Composition of Edge Cities and Downtowns: the New Urban Reality. Economic Development Quarterly. 9: 259-272
[19] Richard D Bingham \& Deborah Kimble.1995. The Industrial Composition of Edge Cities and Downtowns: the New Urban Reality. Economic Development Quarterly. 9: 259-272

[20] Robert Holden \&Tom Turner. 1997. Western Europe, Current City Expansion and the Use of GIS. Landscape and Urban Planning. 36(4): 315-326

[21] Stanback T M. 1991.The New Suburbanization: Challenge to the Central City. Boulder: Westview Press

[22] Wei Li \& Fulong Wu \& Nick Phelps.2008. Chinese characteristics "edge city" development: Analysis of the structure of the transition to a polycentric urban area of Shanghai and Beijing. International Urban Planning. 23(4):2-6

[23] Wenhe Chen.2012. Environmental quality of Kashi economic zone. Chifeng College (Natural Science edition). 28(5): 44-46

[24] Xiao Juan.2003.Research on edge city of Shanghai. Shanghai Normal University

[25] Xingping Wang \& Xinguo Yuan.2009. "Redevelopment" built-up area of Development: Smart Growth of Chinese urban road. Tianjin, China: Third urban redevelopment experts Asian International Seminar Proceedings. 2009-10

[26] Xinguo Yuan \& Xingguo Yuan.2010. Edge of the city on China's development zones Redevelopment reference - in Ningbo Economic and Technological Development Zone. Urban Planning Forum.6:95-101

[27] Yue Deng \& Zheng Wang \& Yongxing Wu.2001.Edge city of Shanhai. Geography. 10:34-39

[28] Zheng Guo \& Jing Meng.2012. Edge of the city of Beijing Case Study. Urban design. 36(4):32-36

[29] Zhifang Tian.2008. High-tech Development Zone, the status quo and the future of our country to explore. Shanxi Architecture. 34(2):79-80 